\title{
Papilite duodenal aguda em bovino. Relato de caso
}

Adony Q Andrade Neto", Jose Augusto B Afonso, Rodolfo JC Souto, Carla L Mendonça, José Claudio A Souza

Programas de Pós-Graduação em Ciência Veterinária, Universidade Federal Rural de Pernambuco (UFRPE), Guarunhos, PE, Brasil

*Autor correspondente

e-mail: adony_neto@hotmail.com

\section{Resumo}

Em bovinos a ocorrência de lesões hepáticas é mais comum devido à intoxicação por plantas, distúrbios metabólicos, infeciosos e traumáticos. Os processos obstrutivos extra-hepáticos do sistema biliar são pouco frequentes nessa espécie. As doenças que afetam o sistema biliar relacionadas aos processos obstrutivos são decorrentes de neoplasias, infecções, processos inflamatórios (colecistite, coledoquite), complexo colangite/colangio-hepatite ( $\mathrm{CCCH}$ ) e papilite duodenal. Este trabalho tem por objetivo relatar a ocorrência de um processo obstrutivo dos ductos biliares extra-hepáticos decorrente de um processo inflamatório das papilas duodenais ou papila de Vater em um bovino procedente de uma propriedade rural do município de Brejão/PE e atendido pela Clínica de Bovinos-UFRPE. 0 animal era criado extensivamente e foi internado por apresentar tremores musculares, andar descoordenado e por ficar deitado por muito tempo. Os principais achados clínicos foram decúbito lateral, apatia, mucosas congestas, opacidade de córnea bilateralmente e esclera ocular ictérica, com blefaroespasmos e lacrimejamento. 0 animal apresentava mioclonias, pele espessada e enrugada principalmente nas partes despigmentadas, como região ventral, pernas e úbere. Os tetos estavam avermelhados, ulcerados e ressecados. Foi constatado ainda taquicardia e hipomotilidade ruminal, e na avaliação das provas de dor, desconforto. Em virtude do quadro clínico desfavorável apresentado pelo animal, foi realizado o sacrifício e necropsia. Os valores hematológicos do bovino revelaram neutrofilia com desvio à esquerda regenerativo, e na bioquímica clínica foram observados valores expressivos para AST e GGT, porém diminuídos para albumina com uma relação albumina/globulina baixa. A necropsia constatou uma vesícula biliar distendida, repleta com conteúdo e aderida à serosa duodenal, o colédoco dilatado e o duodeno mostrando a porção pilórica-duodenal com hipertrofia das glândulas duodenais e duodenite aguda. A Papila de Vater apresentava-se hipertrofiada e edemaciada, comprometendo o fluxo 
biliar e pancreático. A histopatologia revelou uma papilite aguda, dilatação cística, hipertrofia e hiperplasia acinar, e das células da mucosa do colédoco. 0 diagnóstico foi estabelecido a partir dos achados clínicos, das alterações hematológicas, bioquímicas e anatomopatológicos, ao que concluímos que o caso se tratava de uma papilite duodenal aguda. Considerando os achados relatados sobre a ocorrência de um caso incomum de hipertrofia da papila de Vater ou papila duodenal maior em um bovino, cujas manifestações clínicas se assemelham aos casos de fotossensibilização, o presente caso retratou que se tratava de uma enfermidade que impôs uma condição clínica grave, intratável, rara e com desfecho desfavorável. 